\title{
SOFTWARE DEVELOPERS' PERCEPTION OF PROJECT SUCCESS
}

\author{
DOI: 10.17261/Pressacademia.2020.1361 \\ PAP- V.12-2020(25)-p.90
}

\section{Nilufer Alan Anac ${ }^{1}$, Murat Onuk ${ }^{2}$}

${ }^{1}$ Yeditepe University, Department of Business Administration, Istanbul,Turkey. nlfr_alan@hotmail.com, ORCID: 0000-0000-0000-0000

${ }^{2}$ Yeditepe University, Department of Business Administration, Istanbul,Turkey. murat.onuk@yeditepe.edu.tr, ORCID: 0000-0002-9737-7386

\section{To cite this document}

Anac, N.A., Onuk, M. (2020). Software developers' perception of project success. PressAcademia Procedia (PAP), V.12, p.90. Permanent link to this document: http://doi.org/10.17261/Pressacademia.2020.1361

Copyright: Published by PressAcademia and limited licensed re-use rights only.

\section{ABSTRACT}

Purpose- The purpose of this quantitative study is to investigate and define project success according to software project participants in the Turkish Information Techology sector. In this study, the effect of different project management methodologies and education levels were also considered.

Methodology- The study employs a quantitative hypothesis-testing method. The survey instrument of Procaccino, Verner, Shelfer and Gefen (2005) was used in this analysis. In collecting the responses, a 5-point Likert-type scale was used to specify the degree of agreement with each written statement (Procaccino, Verner, Shelfer, \& Gefen, 2005).

Findings- A total of 211 responses were collected. The demografic analysis shows that $31 \%$ (66) of the participants were female and $69 \%$ (145) were male. The average age of the survey participants was 33.9 years. The average number of years working in the IT sector was 9.7. Additionally, the analysis showed that 2 responses were missing, and 1 response only included the Kanban method. Interestingly 66 responses (31\%) were only Scrum, which is one of the Agile methods. Moreover, 11 responses (5\%) were only Waterfall, and 41 responses (19\%) included both Waterfall and Scrum. 48.3\% (102) of the participants used mixed methods, and $40.8 \%(86)$ used at least one Agile method.

Conclusion- During the analysis of survey results, factor analysis, The Kruskal-Wallis test, correlation analysis, regression analysis were used. Factor analysis was applied and nine factors were found and explained $63.526 \%$ of the measurement. These factors were: personal growth, customer requirements, rewards, interpersonal relations, team factors, management, project output, and personal factors. Difference analysis was applied to the demographic variables. As a result, it was found that gender, age group, job position, and education level did not cause a difference in the definition of project success. Work experience created a significant difference in the project output factors and project management methodology created a significant difference in the team factors. As a result of the correlation analysis, in the first correlation, the project output factors and professional growth factors were highly correlated with each other (0.600). The other correlations were as follows: the second correlation is identified between interpersonal relations factors and professional growth factors (0.544), the third correlation was identified between reward and professional growth factors (0.541), the fourth correlation was identified between customers and professional growth factors (0.489), the fifth correlation was identified between team factors and professional growth factors (0.481), and the sixth correlation was identified between personal factors and professional growth factors (0.349). The least correlated variables were the personal and professional growth factors (0.349). According to the regression analysis, the significance was very high ( $p=$ 0.008). This meant that the model was statistically significant and a regression equation exists providing a definition for the project success.

Keywords: Agile, waterfall, project management methodology, project success JEL Codes: C12, C83, M15

\section{REFERENCES}

Procaccino, J. D., Verner, J. M., Shelfer, K. M., \& Gefen, D. (2005). What do software practitioners really think about project success:an exploratory study. The Journal of Systems and Software 78. 